\title{
The Contribution of KONI Towards Medal-Winning Athletes at Aceh Province
}

\author{
Amiruddin $^{1}$, T. M. Jamil ${ }^{2}$, Abdurrahman ${ }^{3}$, and Fitri Ramayana Siregar ${ }^{4}$ \\ ${ }^{1,2,3,4}$ Physical Education, Sport, Health and Recreation Department Faculty of Teacher \\ Training and Education of Syiah Kuala University, Banda Aceh
}

$\left\{{ }^{1}\right.$ amiruddin_ulka@yahoo.com $\}$

\begin{abstract}
The role of KONI as a responsible organization towards medal-winning athletes that still had a lot of propositions. The common proposition that arise nowadays is the lack of the role of KONI as a responsible organization towards medal-winning athletes, as seen from the facts that occurred in Aceh Province there are still many athletes who are forced to live their lives with difficulties, so that they must leave the world of sports immediately to get a better life. This research attempted to reveal the contribution of KONI towards Aceh's medalwinning athletes. The aim of this research is also to describe the contribution of KONI towards Aceh's medal-winning athletes particularly. The approach used in this research is descriptive research. The data sources of this research sourced from the members of KONI Aceh and medal-winning athletes with the context of the contribution of KONI towards Aceh's medal-winning athletes. The data collection used by using observation technique, interview, and questionnaire. In doing this research, the writer as an observer did not involve in the research at all in order to make the results trusted. The writer also used a camera as a needed tool, interviewed sheet, and questionnaire. Based on the results of this research, it can be explained that KONI Aceh had a high sense of contribution to medal-winning athletes. It showed on the giving of extra bonus to the medal-winning athletes and also coaching money to a record breaker athletes. The results of this research are in line with the results that the writer did to PON athletes, KONI claimed that PON athletes are given bonus as well and also an occupation to guarantee their lives in the future. It can be said that KONI Aceh had high attention and contribution towards medal-winning athletes.
\end{abstract}

Keywords: KONI, medal-winning athletes

\section{Introduction}

Number 03 the year 2005 which describes the national sports system that sports are part of the process and the achievement of national development goals so that the existence and role of sports in the life of society, nation and state must be placed in a clear position in the national legal system. The problems of sports both national and regional levels are increasingly complex and a related to the social, economic and cultural dynamics of the people and the nation and the demands of global change so that it is time for the government to pay attention to the whole by observing all relevant aspects, adaptive toward the development of sports and society, as well as legal instruments that is able to support the train and development of national and regional 
sports at present and in the future. The process of handling sports cannot be handled anymore as simply, but it must be handled in more depth and professional.

The main task of the establishment of KONI is to plan, coordinate and carry out coaching and enhancement of the achievements of athletes, referees, coaches, and managers, in order to realize national sports achievements towards international achievement and strengthen national unity and resilience in order to elevate Indonesia's dignity in the international scene.

From most parts of Indonesia, the province of Aceh is one of the provinces that currently implement training sports athletes who stand under KONI. KONI is an institution that has the responsibility and authority as stipulated in the UU above to carry out synergic coordination vertically and horizontally in the framework of managing, developing and developing regional sports through improving the quality of sports. The context of sports, the province of Aceh is an area with a promising athlete potential where it is evident from the many achievements of sports that have been carved, such as PON in West Java Acehnese sports athletes have made achievements from various sports, such as from athletics, and archery. Behind the success of the athletes that have been achieved in each match, the role of the Aceh of KONI as an organization that is responsible for improving sports is very important to increase the athlete's performance so that the desired goals can be achieved and implemented as expected.

Based on the results of observations or data collection it can be explained that every athlete has a profession in different jobs, their work is largely a business which they choose themselves rarely because they are high-achieving athletes, the role of KONI is very minimal so it can be said KONI contribution to athletes achievement has not been run as it should, it can be based on various factors.

Based on the role of KONI as an organization that is responsible for improving performance, there are still many problems that occur. One of the problems that have arisen at this time is the lack of KONI's organization for medal-winning athletes, based on the fact that the field occurred in Aceh Province there are still many athletes who are forced to life with difficulties, so they must leave the world of sports. whereas it is indeed detrimental to KONI Aceh as the organizer of Aceh sports, if medalist athletes no longer focus on training and more focus on finding the adequacy of daily life, surely Aceh will no longer be able to have superior athletes, it happens due to several things one of them the lack of awareness of KONI Aceh in today's outstanding athletes, on the basis of the writing above the author intends to do a paper of scientific work relating to the role of KONI with the title "The Contribution of KONI Toward Medal-Winning Athletes in Aceh Province"

\section{Method}

\subsection{Types of Research}

The types of descriptive research, in which a study that attempts to describe and interpret data, events, and symptoms (phenomena) that exist today. This is based on the opinion of Nazir[1] Descriptive research aims to make descriptive problems in society and the procedures carried out in society, as well as certain situations including the relationship of activities, attitudes, views as well as ongoing processes and influences from certain phenomena.

\subsection{Population and Sample}

The sample in this study consists of 2 people of KONI caretaker and 63 people of Acehnese athletes using a total sampling technique. 


\subsection{Techniques of Data Collection}

Techniques of data collection in this study are:
a. Observation
b. Interview
c. Questionnaire

\subsection{Time and Place of Research}

The research has been carried out at the KONI Aceh building on October 6, 2017, to completion.

\section{$3 \quad$ Result and Discussion}

\subsection{The Result of Research and Discussion}

Based on the results of data collection carried out by using instruments in the form of questionnaires of KONI contribution towards medalist athletes of Aceh Province, obtained the following data

Table 3.1.1 Data for Questions that KONI of Aceh Gives Care in the Form of Work.

\begin{tabular}{|c|l|c|c|}
\hline No & Answer options & Frequency & Percentage \\
\hline 1 & Strongly agree & 28 & 43 \\
\hline 2 & Agree & 21 & 32 \\
\hline 3 & Disagree & 16 & 25 \\
\hline 4 & Strongly disagree & - & - \\
\hline & Jumlah & $\mathbf{6 5}$ & $\mathbf{1 0 0 \%}$ \\
\hline
\end{tabular}

Based on the data in the table 3.1.1, it can be seen that for the KONI of Aceh questions giving care in the form of work is as much as $43 \%$ of respondents or 28 people strongly agree, $32 \%$ of respondents or 21 people agree, and the remaining $25 \%$ of respondents or 16 people disagree.

Table 3.1.2 Data for Questions that KONI of Aceh Provides Care in Bonus Forms.

\begin{tabular}{|l|l|l|l|}
\hline No & Answer options & Frequency & Percentage \\
\hline 1 & Strongly Agree & 35 & 52 \\
\hline 2 & Agree & 28 & 43 \\
\hline 3 & Disagree & - & - \\
\hline 4 & $\begin{array}{l}\text { Strongly } \\
\text { Disagree }\end{array}$ & 3 & 5 \\
\hline \multicolumn{2}{|l|}{ Total } & $\mathbf{6 5}$ & $\mathbf{1 0 0 \%}$ \\
\hline
\end{tabular}

Based on the data in the table 3.1.2, it was found that that for the questions that KONI Aceh gives care in the form of bonuses is as much as $52 \%$ of respondents or 35 people strongly agree, $43 \%$ of respondents or 28 people agree, and the remaining $5 \%$ of respondents or 3 people strongly disagree. 
Table 3.1.3 Data for Questions that KONI of Aceh Gives Attention Only to Athletes who achieve on PON Only.

\begin{tabular}{|c|l|c|c|}
\hline No & Answer options & Frequency & Percentage \\
\hline 1 & Strongly Agree & 25 & 39 \\
\hline 2 & Agree & 16 & 25 \\
\hline 3 & Disagree & 12 & 18 \\
\hline 4 & Strongly Disagree & 12 & 18 \\
\hline \multicolumn{2}{|c|}{ Total } & $\mathbf{6 5}$ & $\mathbf{1 0 0 \%}$ \\
\hline
\end{tabular}

Based on the data in the table 3.1.3 it was found that for the questions that KONI of Aceh gives attention only to athletes who excel in PON is as much as $39 \%$ of respondents or 25 people strongly agree, $25 \%$ of respondents or 16 people agree, $18 \%$ of respondents or 12 people argue that they disagree and the remaining $18 \%$ of respondents or 12 people strongly disagree.

Table 3.1.4 Data for Questions that KONI of Aceh Provides Assistance To Athletes Who Have Achievements.

\begin{tabular}{|c|l|c|c|}
\hline No & $\begin{array}{c}\text { Answer } \\
\text { options }\end{array}$ & Frequency & Percentage \\
\hline 1 & Strongly Agree & 28 & 43 \\
\hline 2 & Agree & 19 & 29 \\
\hline 3 & Disagree & 9 & 14 \\
\hline 4 & $\begin{array}{l}\text { Strongly } \\
\text { Disagree }\end{array}$ & 9 & 14 \\
\hline \multicolumn{2}{|c|}{ Total } & $\mathbf{6 5}$ & $\mathbf{1 0 0 \%}$ \\
\hline
\end{tabular}

Based on the data in table 3.1.4 it can be seen that for the question items whether Aceh KONI provides assistance to athletes who have achievements is as much as $43 \%$ of respondents or 28 people strongly agree, $29 \%$ of respondents or 19 people agree, $14 \%$ of respondents or 9 people disagree and the remaining $14 \%$ of respondents or 9 people strongly disagree.

Table 3.1.5 Data for Questions that KONI of Aceh Provides Assistance in Various Forms.

\begin{tabular}{|c|l|c|c|}
\hline No & Answer options & Frequency & Percentage \\
\hline 1 & Strongly Agree & 34 & 52 \\
\hline 2 & Agree & 25 & 39 \\
\hline 3 & Disagree & - & - \\
\hline 4 & $\begin{array}{l}\text { Strongly } \\
\text { Disagree }\end{array}$ & 6 & 9 \\
\hline \multicolumn{2}{|c|}{ Total } & $\mathbf{6 5}$ & $\mathbf{1 0 0 \%}$ \\
\hline
\end{tabular}

Based on the data in the table 3.1.5, it can be found that for the questions that KONI Aceh provide assistance in various forms, as many as $52 \%$ of respondents or 34 people strongly agree, $39 \%$ of respondents or 25 people agree, and $9 \%$ of respondents or 6 people strongly disagree. 
Table 3.1.6 Data for Questions that KONI of Aceh can assist in the Future of Athletes.

\begin{tabular}{|c|l|c|c|}
\hline No & Answer options & Frequency & Percentage \\
\hline 1 & Strongly Agree & 34 & 52 \\
\hline 2 & Agree & 22 & 34 \\
\hline 3 & Disagree & 3 & 5 \\
\hline 4 & $\begin{array}{l}\text { Strongly } \\
\text { Disagree }\end{array}$ & 6 & 9 \\
\hline \multicolumn{2}{|c|}{ Total } & $\mathbf{6 5}$ & $\mathbf{1 0 0 \%}$ \\
\hline
\end{tabular}

Based on the data in the table 3.1.6, it can be seen that for the questions about the form of contribution given by KONI Aceh can help the future of athletes as much as $52 \%$ of respondents or 34 people strongly agree, $34 \%$ of respondents or 22 people agree, $5 \%$ of respondents or 3 people disagree and the remaining $9 \%$ of respondents or 6 people strongly disagree.

Table 3.1.7 Data for Questions that KONI of Aceh Gives Life Insurance for Every Athlete with Achievement.

\begin{tabular}{|c|l|c|c|}
\hline No & Answer options & Frequency & Percentage \\
\hline 1 & Strongly Agree & 37 & 57 \\
\hline 2 & Agree & 19 & 29 \\
\hline 3 & Disagree & 3 & 5 \\
\hline 4 & $\begin{array}{l}\text { Strongly } \\
\text { Disagree }\end{array}$ & 6 & 9 \\
\hline \multicolumn{2}{|c|}{ Total } & $\mathbf{6 5}$ & $\mathbf{1 0 0 \%}$ \\
\hline
\end{tabular}

Based on the data in table 3.1.7, it can be seen that for the question items whether the KONI of Aceh stated the availability of life insurance for every outstanding athlete is $57 \%$ of respondents or 37 people strongly agree, $29 \%$ of respondents or 19 people agree, $5 \%$ of respondents or 3 people disagree, and $9 \%$ of respondents or 9 people strongly disagree.

Table 3.1.8 Data For Question that KONI of Aceh Only Gives Attention to Outstanding Athletes.

\begin{tabular}{|c|l|c|c|}
\hline No & Answer options & Frequency & Percentage \\
\hline 1 & Strongly Agree & 37 & 57 \\
\hline 2 & Agree & 19 & 29 \\
\hline 3 & Disagree & 3 & 5 \\
\hline 4 & $\begin{array}{l}\text { Strongly } \\
\text { Disagree } \\
\text { Total }\end{array}$ & 6 & 9 \\
\hline \multicolumn{2}{|c|}{} \\
\hline
\end{tabular}

Based on the data in table 3.1.8, it shows that for the question whether the KONI of Aceh only gives attention to outstanding athletes is as many as $57 \%$ of respondents or 37 people strongly agree, $29 \%$ of respondents or 19 people agree, $5 \%$ of respondents or 3 people disagree, and $9 \%$ of respondents or 9 people strongly disagree. 
Table 3.1.9 Data for Question that KONI of Aceh Never Gives Any Promises to Any Outstanding Athletes.

\begin{tabular}{|c|c|c|c|}
\hline No & Answer options & Frequency & Percentage \\
\hline 1 & Strongly agree & 7 & 11 \\
\hline 2 & Agree & 18 & 28 \\
\hline 3 & Disagree & 31 & 48 \\
\hline 4 & Strongly disagree & 9 & 14 \\
\hline \multicolumn{2}{|r|}{ Total } & 65 & $100 \%$ \\
\hline
\end{tabular}

Based on the data in Table 3.1.9, it can be seen that for the question items that KONI of Aceh have never given any promises to every achieving athlete is as many as $48 \%$ of respondents or 31 people disagree, $28 \%$ of respondents or 18 people agree, $11 \%$ of respondents or 7 people strongly agree, and $14 \%$ of respondents or 9 people strongly disagree.

Table 3.1.10 Data For Questions that KONI of Aceh Will Only Provide Bonuses Without Any Bonds Against Achieving Athletes

\begin{tabular}{|c|l|c|c|}
\hline No & Answer options & Frequency & Percentage \\
\hline 1 & Strongly agree & 28 & 43 \\
\hline 2 & Agree & 16 & 25 \\
\hline 3 & Disagree & 5 & 8 \\
\hline 4 & $\begin{array}{l}\text { Strongly } \\
\text { disagree }\end{array}$ & 16 & 25 \\
\hline \multicolumn{2}{|c|}{ Total } & $\mathbf{6 5}$ & $\mathbf{1 0 0 \%}$ \\
\hline
\end{tabular}

Based on the data in Table 3.1.10, it shows that for question that KONI of Aceh will only give bonuses without any ties to achievement athletes is as many as $43 \%$ of respondents or 28 people strongly agree, $25 \%$ of respondents or 16 people agree, $8 \%$ of respondents or 5 people disagree, and $25 \%$ respondent or 16 people strongly disagree.

Table 3.1.11 Data for Question that KONI of Aceh Provides Attention Only For One-sided Interest.

\begin{tabular}{|c|l|c|c|}
\hline No & \multicolumn{1}{|c|}{$\begin{array}{c}\text { Answer } \\
\text { options }\end{array}$} & Frequency & Percentage \\
\hline 1 & Strongly agree & 28 & 43 \\
\hline 2 & Agree & 13 & 20 \\
\hline 3 & Disagree & 15 & 23 \\
\hline 4 & $\begin{array}{l}\text { Strongly } \\
\text { disagree }\end{array}$ & 9 & 14 \\
\hline \multicolumn{2}{|c|}{ Total } & $\mathbf{6 5}$ & $\mathbf{1 0 0 \%}$ \\
\hline
\end{tabular}

Based on the data in Table 3.1.11, it can be seen that for the question items that KONI of Aceh pays attention only to one-sided interests is as many as $43 \%$ of respondents or 28 people 
strongly agree, $20 \%$ of respondents or 13 people agree, $23 \%$ of respondents or 15 people disagree, and $14 \%$ of respondents or 9 people strongly disagree.

Table 3.1.12 Data for Question that KONI of Aceh Gives Attention Because You Are the Medalist Winner in the National Championship.

\begin{tabular}{|c|l|c|c|}
\hline No & Answer options & Frequency & Percentage \\
\hline 1 & Strongly agree & 21 & 32 \\
\hline 2 & Agree & 19 & 29 \\
\hline 3 & Disagree & 9 & 14 \\
\hline 4 & $\begin{array}{l}\text { Strongly } \\
\text { Disagree } \\
\text { Total }\end{array}$ & 16 & 25 \\
\hline \multicolumn{2}{|c|}{} \\
\hline
\end{tabular}

Based on the data in table 3.1.12, it shows that for questions that KONI of Aceh to pay attention because you are the medalist winner in the national championship is as many as $32 \%$ of respondents or 21 people strongly agree, $29 \%$ of respondents or 19 people agree, $14 \%$ of respondents or 9 people disagree, and $25 \%$ respondent or 16 people strongly disagree.

Table 3.1.13 Data for Question that KONI of Aceh Gives Attention to Achieving Athletes at the Regional Level Only.

\begin{tabular}{|c|l|c|c|}
\hline No & Answer options & Frequency & Percentage \\
\hline 1 & Strongly agree & 19 & 29 \\
\hline 2 & Agree & 14 & 22 \\
\hline 3 & Disagree & 19 & 29 \\
\hline 4 & Strongly disagree & 13 & 20 \\
\hline \multicolumn{2}{|c|}{ Total } & $\mathbf{6 5}$ & $\mathbf{1 0 0 \%}$ \\
\hline
\end{tabular}

According to the data on table 3.1.13 about KONI Aceh's question in giving attention to excellent athletes at the regional level itself was $29 \%$ of respondents or 19 respondents strongly agree to that information. Then, $22 \%$ or 14 respondents agree, $29 \%$ or 19 respondents disagree, and the remaining respondents which are $20 \%$ or 13 people strongly disagree with that statement.

Table 3.1.14 Data for Questions that KONI of Aceh prioritizes to excellent athletes in Sports Branches.

\begin{tabular}{|c|l|c|c|}
\hline No & $\begin{array}{c}\text { Answers } \\
\text { options }\end{array}$ & Frequency & Percentage \\
\hline 1 & Strongly Agree & 34 & 52 \\
\hline 2 & Agree & 16 & 25 \\
\hline 3 & Disagree & 9 & 14 \\
\hline 4 & $\begin{array}{l}\text { Strongly } \\
\text { Disagree }\end{array}$ & 6 & 9 \\
\hline \multicolumn{2}{|c|}{ Total } & $\mathbf{6 5}$ & $\mathbf{1 0 0 \%}$ \\
\hline
\end{tabular}


The data on table 3.1.14 showed that KONI Aceh's question to excellent athletes in Sports Branches for being prioritized was $52 \%$ or 34 respondents strongly agree, $25 \%$ or 16 respondents agree, and the respondents who disagree was $14 \%$ or 9 respondents. The remaining respondents which were $9 \%$ or 6 respondents strongly disagree with the question.

Table 3.1.15 Data for Questions that KONI of Aceh gives attention just by words without maximum help.

\begin{tabular}{|c|l|c|c|}
\hline No & Answer options & Frequency & Percentage \\
\hline 1 & Strongly Agree & 18 & 28 \\
\hline 2 & Agree & 13 & 20 \\
\hline 3 & Disagree & 25 & 38 \\
\hline 4 & Strongly Disagree & 9 & 14 \\
\hline \multicolumn{2}{|c|}{ Total } & $\mathbf{6 5}$ & $\mathbf{1 0 0 \%}$ \\
\hline
\end{tabular}

Based on the data from table 3.1.15, it showed that $28 \%$ o 18 respondents strongly agree to the statement about attention given by KONI Aceh which is just by words without any maximum help. Next, $20 \%$ or 13 respondents agree, $38 \%$ or 25 respondents disagree, and the rest was $14 \%$ or 9 respondents strongly disagree with the statement.

Table 3.1.16 Data for the question that KONI of Aceh always provides attention towards achievement athletes.

\begin{tabular}{|c|l|c|c|}
\hline No & Answer options & Frequency & Percentage \\
\hline 1 & Strongly Agree & 25 & 38 \\
\hline 2 & Agree & 12 & 18 \\
\hline 3 & Disagree & 12 & 18 \\
\hline 4 & Strongly Disagree & 16 & 25 \\
\hline \multicolumn{2}{|c|}{ Total } & $\mathbf{6 5}$ & $\mathbf{1 0 0 \%}$ \\
\hline
\end{tabular}

Based on the data from table 3.1.16, it showed that KONI of Aceh always provides attention towards achievement athletes as many as $38 \%$ or 25 respondents strongly agree, $18 \%$ or 12 respondents agree, $18 \%$ or 12 respondents disagree and the remaining $25 \%$ or 16 respondents strongly disagree.

Table 3.1.17 Data for the question that KONI of Aceh always gives bonus towards achievement athletes to guarantee their future lives.

\begin{tabular}{|c|l|c|c|}
\hline No & Answer options & Frequency & Percentage \\
\hline 1 & Strongly Agree & 28 & 43 \\
\hline 2 & Agree & 16 & 25 \\
\hline 3 & Disagree & 16 & 25 \\
\hline 4 & Strongly Disagree & 5 & 8 \\
\hline \multicolumn{2}{|c|}{ Total } & $\mathbf{6 5}$ & $\mathbf{1 0 0 \%}$ \\
\hline
\end{tabular}

According to the data from table 3.1.17, it showed that KONI of Aceh always gives bonus towards achievement athletes to guarantee their future lives as many as $43 \%$ or 28 respondents 
strongly agree, $25 \%$ or 16 respondents agree, $25 \%$ or 16 respondents disagree and the remaining $8 \%$ or 5 respondents strongly disagree.

Based on the data from table 3.1.18, it showed that KONI of Aceh always gives support towards athletes' achievement only for uncertain lure as many as $48 \%$ or 31 respondents strongly agree, $34 \%$ or 22 respondents agree, $14 \%$ or 9 respondents disagree and the remaining $5 \%$ or 3 respondents strongly disagree.

Table 3.1.18 Data for the question that KONI of Aceh always gives support towards athletes' achievement only for the uncertain lure.

\begin{tabular}{|c|l|c|c|}
\hline No & Answer options & Frequency & Percentage \\
\hline 1 & Strongly Agree & 31 & 48 \\
\hline 2 & Agree & 22 & 34 \\
\hline 3 & Disagree & 9 & 14 \\
\hline 4 & Strongly Disagree & 3 & 5 \\
\hline \multicolumn{2}{r|}{ Total } & $\mathbf{6 5}$ & $\mathbf{1 0 0 \%}$ \\
\hline
\end{tabular}

Table 3.1.19 Data for the question; due to the lack of achievement, whether Aceh KONI should still provide support for the athletes or not.

\begin{tabular}{|c|l|c|c|}
\hline No & Answer options & Frequency & Percentage \\
\hline 1 & Strongly Agree & 28 & 43 \\
\hline 2 & Agree & 12 & 18 \\
\hline 3 & Disagree & 16 & 25 \\
\hline 4 & Strongly Disagree & 9 & 14 \\
\hline \multicolumn{2}{|c|}{ Total } & $\mathbf{6 5}$ & $\mathbf{1 0 0 \%}$ \\
\hline
\end{tabular}

Based on the data in table 3.1.19, it can be seen that for the question; due to the lack of achievement, whether Aceh KONI should still provide support for the athletes or not, $43 \%$ of respondents or 28 people strongly agreed, $18 \%$ of respondents or 12 people agreed, $25 \%$ of respondents or 16 people argued that they did not agree and the remaining $14 \%$ of respondents or 9 people strongly disagreed.

Table 3.1.20 Data for the question of whether Aceh KONI should provide other alternatives for athletes' future if they failed in achieving medals.

\begin{tabular}{|c|l|c|c|}
\hline No & $\begin{array}{c}\text { Answer } \\
\text { options }\end{array}$ & Frequency & Percentage \\
\hline 1 & Strongly Agree & 34 & 52 \\
\hline 2 & Agree & 25 & 38 \\
\hline 3 & Not Agree & 3 & 5 \\
\hline 4 & $\begin{array}{l}\text { Strongly } \\
\text { Disagree }\end{array}$ & 3 & 5 \\
\hline \multicolumn{2}{|l|}{ Total } & $\mathbf{6 5}$ & $\mathbf{1 0 0 \%}$ \\
\hline
\end{tabular}

Based on the data in table 3.1.20 it can be seen that for the question of whether Aceh KONI should provide other alternatives for athletes' future if they failed in achieving medals, $52 \%$ of 
respondents or 34 people thought strongly agree, $38 \%$ of respondents or 25 people agreed, $5 \%$ of respondents or 3 people argued that they disagreed and the remaining $5 \%$ of respondents or 3 people strongly disagreed.

\subsection{Data of Observation Result}

Based on data from research observations about Aceh KONI contribution for the highachieving athletes, the writer can describe it as follows:

Table 3.2.1 Observation about Aceh KONI contribution for PON medalist athletes.

\begin{tabular}{|l|c|c|}
\hline \multirow{2}{*}{\multicolumn{1}{|c|}{ Type of Observation }} & \multicolumn{2}{c|}{ Explanation } \\
\cline { 2 - 3 } & Yes & No \\
\hline $\begin{array}{l}\text { Job Recommendation from } \\
\text { KONI }\end{array}$ & $\sqrt{ }$ & - \\
\hline Supporting Money & $\sqrt{ }$ & - \\
\hline Bonus & $\sqrt{ }$ & - \\
\hline Try Out & $\sqrt{ }$ & - \\
\hline
\end{tabular}

Based on observations that the author has done, it can be concluded that the Aceh KONI has given attention or contribution to every outstanding athlete. This is proven by the table above that each athlete was given a job recommendation, supporting money, bonus, and try out to keep honing their skills.

\subsection{Result of Interview}

Based on the results of the interview that the author did to the Aceh KONI General Secretary, that is Mr. Nasir, the writer concluded that the Aceh KONI had a very high contribution for high-achieving athletes. It was shown by giving bonuses to medal winners as well as supporting money, and even additional bonuses to record breakers. In order to improve the athlete's achievement, the Aceh KONI did Reward and Punishment approach which means that if the achievement is better than the facilities provided would be better, but within a certain limit if the achievement continues to be lower, there is a possibility that the athlete would be replaced with an athlete or another branch.

Based on the result of interview conducted with Mr. T Rayuan Sukma, the chairman of LITBANG, the writer could explain that the result of the interview was exactly the same as what was explained by Mr. Nasir as Aceh KONI General Secretary which means that every athlete who had achievements at the PON and National Championship would still be given bonuses and job recommendation so that athletes could focus on their achievements without feeling fear of losing future especially in working area.

\section{Conclusion and Suggestion}

\subsection{Conclusion}

Based on the results of data collection and data analysis that has been carried out, some conclusions can be drawn as follows:

a. The KONI of Aceh officers has a high level of contribution for the medal-winning athletes. 
b. The average respondent rated the KONI of Aceh officers has a high level of contribution for athletes who won medals with an average score of the result is $63 \%$ or in the high category.

c. The percentage of the level of contribution of the KONI of Aceh officers to the medal winners is $85 \%$ or in the high category, and the remaining $15 \%$ is in the medium category.

\subsection{Suggestion}

Based on the conclusions above, the authors propose some suggestions as follows:

a. To make athletes continue to get the best achievement, it is expected that KONI must provide future guarantees to high-achieving athletes.

b. For athletes to be able to train optimally and continue to develop their potential, it is hoped that Aceh KONI not only gives attention to those who win in PON, but that contribution is also given to athletes who win the championship in Kejurnas and other championships.

The KONI of Aceh and Aceh government should monitor athletes' potential so that athletes can maintain their condition.

\section{REFERENCES}

[1] M. Nazir, Metode penelitian. Jakarta: Ghalia Indonesia, 2009. 